\title{
Interactive comment on "Influence of Estuarine Tidal Mixing on Structure and Spatial Scales of Large River Plumes” by Alexander Osadchiev et al.
}

Alexander Osadchiev et al.

osadchiev@ocean.ru

Received and published: 10 April 2020

The comment was uploaded in the form of a supplement:

https://www.ocean-sci-discuss.net/os-2019-119/os-2019-119-AC3-supplement.pdf

Interactive comment on Ocean Sci. Discuss., https://doi.org/10.5194/os-2019-119, 2019. 